\title{
B-mode and Doppler ultrasonography in the assessment of the common carotid arteries of equines and mules and the relation with body mass, age and neck circumference ${ }^{1}$
}

\author{
Jéssica L. Fogaça ${ }^{2}$ (D), Maria C.R. Castiglioni ${ }^{3}$, Michel C. Vettorato ${ }^{3}$, \\ Danilo G.A. Andrade ${ }^{3}$, José N.P. Puoli-Filho ${ }^{3}$, Marco A.R. Fernandes ${ }^{4}$ \\ and Vânia M.V. Machado ${ }^{3 *}$
}

\begin{abstract}
Fogaça J.L., Castiglioni M.C.R., Vettorato M.C., Andrade D.G.A., Puoli-Filho J.N.P., Fernandes M.A.R. \& Machado V.M.V. 2019. B-mode and Doppler ultrasonography in the assessment of the common carotid arteries of equines and mules and the relation with body mass, age and neck circumference. Pesquisa Veterinária Brasileira 39(1):75-84. Departamento de Reprodução Animal e Radiologia Veterinária, Faculdade de Medicina Veterinária e Zootecnia, Universidade Estadual Paulista, Campus Botucatu, Rua Prof. Dr. Walter Mauricio Correra s/n, Rubião Junior, Botucatu, SP 18618-970, Brazil. E-mail: vania.mv.machado@unesp.br

As age increases, changes in cardiovascular anatomy and physiology occur, even in the absence of disease. Thus, studies of vessel hemodynamics are considered primordial to detect any cardiovascular changes. The objective of this study has been to describe the parameters of B-mode and spectral Doppler ultrasonography in the evaluation of the common carotid arteries of 11 equine and 11 mules, and correlate with age, body mass and neck circumferences. The diameters, intima - media thickness (IMT), resistivity index (RI), pulsatility index (PI), systolic velocity (SV), diastolic velocity (DV), maximum velocity (MV), vascular flow index (VFI), body mass, age, circumference and neck length. Ultrasonographic variables were evaluated in three different region called cranial, middle and caudal. Equine females presented higher values regarding the body mass, age and neck length, as compared to the neck circumferences of the animals, those of the mules were superior. The age of the mules had a positive correlation with the body mass, diameter and neck circumferences, it has a negative correlation between age and vessel diameters. The body mass of the mules had a positive correlation with age and vessel diameters, and with vessel diameters and neck circumferences in equine females. The RI and PI variables had a positive correlation with body mass for mules, and with age for equine females. The DV had a negative correlation with body mass for both equine and mule females. Regarding the variables MV and VFI, age correlated negatively for mules, while it was not significant for equine females. It found a difference between equine females and mules in the correlations performed, with body mass, age, neck circumferences and between B-mode and Doppler ultrasonography variables.
\end{abstract}

INDEX TERMS: B-mode, Doppler, ultrasonography, carotid arteries, equines, mules, body mass, age, neck circumference, horses.

\footnotetext{
${ }^{1}$ Received on April 13, 2018.

Accepted for publication on May 29, 2018.

${ }^{2}$ Departamento de Reprodução Animal e Radiologia Veterinária, Faculdade de Medicina Veterinária e Zootecnia, Universidade Estadual Paulista (Unesp), Campus Botucatu, Distrito de Rubião Junior, Botucatu, SP 18618-970, Brazil.

${ }^{3}$ Faculdade de Medicina Veterinária e Zootecnia, Universidade Estadual Paulista (Unesp), Campus Botucatu, Distrito de Rubião Junior, Botucatu, SP 18618-970. *Corresponding author: vania.mv.machado@unesp.br

${ }^{4}$ Faculdade de Medicina, Universidade Estadual Paulista (Unesp), Campus Botucatu, Distrito de Rubião Junior, Botucatu, SP 18618-970.
}

RESUMO.- [Estudo de ultrassonografia modo-B e Doppler na avaliação das artérias carótidas comuns de equinos e muares e a relação com o peso, idade e a circunferência do pescoço.] Com o aumento da idade ocorrem alterações na anatomia e fisiologia cardiovascular, mesmo na ausência de doenças. Assim, os estudos da hemodinâmica dos vasos são considerados primordiais para detectar quaisquer alterações cardiovasculares. Esse trabalho tem como objetivo descrever 
as variáveis de ultrassonografia modo-B e Doppler espectral na avaliação das artérias carótidas comuns de 11 fêmeas equinas e 11 muares, e correlacionar com idade, massa corpórea e circunferências dos pescoços. Para tais procedimentos foram avaliados os diâmetros, espessura da camada íntima média (EIM), índice de resistividade (IR), índice de pulsatilidade (IP), velocidade sistólica (VS), velocidade diastólica (VD), velocidade máxima (VM), índice de vascularização de fluxo (IVF), massa corpórea, idade, circunferências e comprimentos dos pescoços. As variáveis ultrassonográficas foram avaliadas em três regiões diferentes denominados de crania médio e caudal. As fêmeas equinas apresentaram valores maiores referente ao massa corpórea, idade e comprimento dos pescoços, já em relação às circunferências dos pescoços dos animais, as dos muares foram superiores. A idade dos muares possuiu correlação positiva com a massa corpórea, diâmetro e com as circunferências dos pescoços, com as fêmeas equinas, possui correlação negativa entre idade e os diâmetros dos vasos. A massa corpórea dos muares teve correlação positiva com idade e diâmetros dos vasos, já às fêmeas equinas com diâmetros dos vasos e as circunferências dos pescoços. As variáveis IR e IP tiveram correlação positiva com a massa corpórea para os muares, $\mathrm{e}$ com idade para fêmeas equinas. O VD teve correlação negativa com a massa corpórea tanto para as fêmeas equinas quanto nos muares. Já as variáveis VM e IVF, a idade correlacionou negativamente para os muares, enquanto não foi significativo para as fêmeas equinas. Averiguou diferença entre fêmeas equinas e muares nas correlações realizadas, com a massa corpórea, idade, circunferências dos pescoços e entre as variáveis da ultrassonografia modo-B e Doppler.

TERMOS DE INDEXAÇÃO: Ultrassonografia, modo-B, Doppler, artéria carótida, equinos, muares, peso, idade, circunferência do pescoço.

\section{INTRODUCTION}

In equines, the common carotid artery is considered an important vessel. It irrigates the brain, neck and head and originates the internal carotid, external carotid and occipital arteries, besides several collateral branches, among them the muscular, tracheal and esophageal branches and also the cranial and caudal thyroid, ascending pharyngeal and parotid arteries (Getty 1981, Khamas et al. 2002, Ozgel et al. 2004, Krupinski et al. 2006). The diseases of the central nervous system (CNS) in equines and mules are a relatively important part of those treated by the veterinarian (Pessoa et al. 2014, Aguiar et al. 2014, Aguiar 2015).

In human medicine, the evaluation of the carotid is a fundamental routine examination due to the frequent occurrence of atheromas. However, atherosclerotic plaques are not so frequent in veterinary medicine, although there are already reports of its incidence in dogs and horses (Hess et al. 2003, Rosa et al. 2003, Ribeiro \& Shintaku 2004, Aguiar et al. 2014). Another disturbance that affects the common carotid arteries is stenosis secondary to traumatic, neoplastic or inflammatory processes (Bonamigo \& Lucas 2007, Freitas et al. 2008, Kandiah et al. 2014). Other diseases that can also affect these great arteries are atherosclerosis, stiffening secondary to senility or chronic lesions and dissection (Mendes \& Themudo Barata 2008).

The guttural pouch is a structure which exists in horses and mules and is positioned between the base of the skull and the atlas. This structure consists of air-filled diverticula of the ear tubes (Eustachian), which communicate between the middle ear and the pharynx (Borges et al. 2005, Hayah 2011). There are diseases that affect the guttural sac and some of them are related to the carotid arteries, such as the aneurysm and fungal erosion of the internal carotid artery, which can seriously compromise this structure and even lead to the death of the animal in a few minutes. This is why diagnostic methods such as conventional or two-dimensional mode (B-mode) and spectral Doppler ultrasound can aid in the diagnosis of these diseases (Hayah 2011, Aguiar 2015).

B-mode ultrasonography is a two-dimensional, non-invasive and safe imaging modality that can be used to evaluate organs and tissues in real time. This technique allows the study of the diameter and thickness of the intima-media layer (IMT) of the common carotid arteries (Carvalho 2009). Spectral Doppler ultrasonography, on the other hand, is a tool that, coupled with conventional ultrasonography, allows the evaluation of the blood flow through the analysis of some variables such as resistivity index (RI), pulsatility index (PI), systolic velocity (SV), diastolic velocity (DV), maximal velocity (MV) and vascular flow index (VFI) (Cipone et al. 1997, Khamas et al. 2002, Torres et al. 2007, Aguiar 2015). Besides supplying information on the blood flow, the resistivity index (RI) and pulsatility index (PI) also inform on vessel impedance and compliance (Bailey et al. 2012, Aguiar 2015).

As a consequence of aging alterations take place in cardiovascular anatomy and physiology which are not considered pathological (Mendes \& Themudo Barata 2008). In these cases, studies of vessel hemodynamics are primordial to detect any cardiovascular alterations, whether they are due to senility or to pathological processes (Paiva-de-Souza et al. 2010, Aguiar 2015). This study aimed at describing the B-mode and Doppler ultrasonography variables in the common carotid arteries of equine females and mules and at correlating them with age, body mass and neck circumferences in these animals.

\section{MATERIALS AND METHODS}

This study has been approved by the Animal Ethics Committe (Comissão de Ética no Uso de Animais, CEUA) of Faculdade de Medicina Veterinária e Zootecnia de Botucatu (FMVZ/Unesp) (Protocol no. 0100/2017) and carried out at Fazenda Edgárdia, Unesp Campus Botucatu, Faculdade de Medicina Veterinária e Zootecnia (FMVZ). Twenty-two animals belonging to the division of education, research and extension in equidae of FMVZ, Unesp Botucatu were used. The animals were classified in two groups: 11 healthy equine females of undefined breed (UB), with body mass between 348 and 486 kilograms (kg) and aged from 5 to 25 years, and 11 healthy mules (six males and five females) with body mass between 350 and $462 \mathrm{~kg}$, aged from 4 to 12 years.

For the ultrasound examinations, the animals were taken to the individual containments by professional handlers. During the exams the animals were not subjected to fluid or solid food fasting nor given sedatives, to avoid any hemodynamic changes. For the ultrasound examinations, isopropyl alcohol was applied in the region to be examined at the concentration of $30 \%$ water and $70 \%$ alcohol, followed by silicone gel to protect the transducers. Alcohol dispenses with the need for trichotomy and, along with the gel, improves the conduction of ultrasound waves. The animals were positioned according to their convenience; however, all were kept with their heads above their withers, which became the standard, comfortable positioning. 
Ultrasound examinations were performed using equipment of the MyLab ${ }^{\circledR} 30$ model from the Italian manufacturer Esaote. A cardiac pre-set was used for the analysis of the flow of the common carotid arteries. The pre-set allows the evaluation of high-flow structures without alteration of the angle of insonation. A linear transducer (3.0 to 11.0 megahertz (MHz), made by Esaote, Italy) was used to obtain the B-mode images, and a convex transducer $(1.0$ to $8.0 \mathrm{MHz}$, also made by Esaote, Italy) to obtain spectral Doppler images.

The B-mode and spectral Doppler ultrasounds were done in three regions of the neck: caudal, middle and cranial (Fig.1). They were then analyzed and processed to select the PI for the spectral Doppler ultrasonography images, to obtain the blood flow variables (PI, RI, SV, DV, MV and FVI). The B-mode images, on the longitudinal and transversal planes, were used for measuring the intima-media thickness (IMT) and the diameters of the common carotid arteries of the animals.

The anatomic spots in these regions were classified as caudal, middle and cranial measurement points. The caudal point was determined by a dorsoventral line tangent caudally to the seventh cervical vertebra. The middle point was considered as a dorsoventral line tangent caudally to the articular fovea of the fourth cervical vertebra. The cranial point was identified as a line tangent dorsally to the condyles of the occipital bone and ventrally to the angle of the jaw. All values of PI, RI, SV, DV, MV, VFI, IMT and the diameters of the common arteries, right and left, were analyzed and, after that, entered into a table drawn up using Microsoft Excel 2013 for statistical analysis, using The SAS System 9.0 software for the calculation of the mean and standard deviation in each group. Spearman's correlation test was applied between the variables of interest. The base of the neck, middle and cranial (near the head) circumferences of the necks were measured using a millimetric measuring tape, along with the length of the neck, to evaluate their correlation with body mass, age, diameter and IMT of the walls of the common carotid arteries, right and left, of the animals (Fig.2) and immediately analyzed statistically. This study considered a significance of $5 \%$, that is, the null hypothesis was rejected when $\mathrm{p}$-value was smaller or equal to 0.05

\section{RESULTS}

Table 1 illustrates the mean and standard deviation of the variables body mass, age, neck and base of the neck, middle and cranial circumferences in the equine and mule females.

It should be noted that this sample had an average body mass of $368 \mathrm{~kg}$ in mules and $413 \mathrm{~kg}$ in equine females, while the average age was 8 years for mules and 14 for equine females.

As for the neck circumferences, the base of the neck averaged 104 centimeters $(\mathrm{cm})$ in the mules as well as in the equine females. The medium region averaged $87 \mathrm{~cm}$ in the mules and $83 \mathrm{~cm}$ in the equine females; the cranial variable averaged $71 \mathrm{~cm}$ both in the mules and in the equine females. Neck length measured an average of $39 \mathrm{~cm}$ in the mules and $44 \mathrm{~cm}$ in the equine females. Table 2 illustrates two statistics: the correlation value $(r)$ and the p-value. The correlation values $(r)$ indicate whether the correlation is positive, that is, if the increase in one variable is associated with the increase of the associated variable, or negative, when the variables are indirectly proportional.

In Table 2 it can be observed that the age of the mules had positive correlations with the body mass $(\mathrm{p}=0.0140)$, base of the neck $(\mathrm{p}<0.001)$, medium $(\mathrm{p}=0.0003)$, cranial $(\mathrm{p}<0.001)$ and longitudinal $(\mathrm{p}<0.001)$ and transversal diameter of the vessel $(\mathrm{p}<0.001)$.

The body mass variable showed positive correlations with age $(\mathrm{p}=0.0140)$, longitudinal diameter $(\mathrm{p}=0.0407)$, transversal diameter $(p=0.0403)$ and base of the neck $(p<0.001)$. There
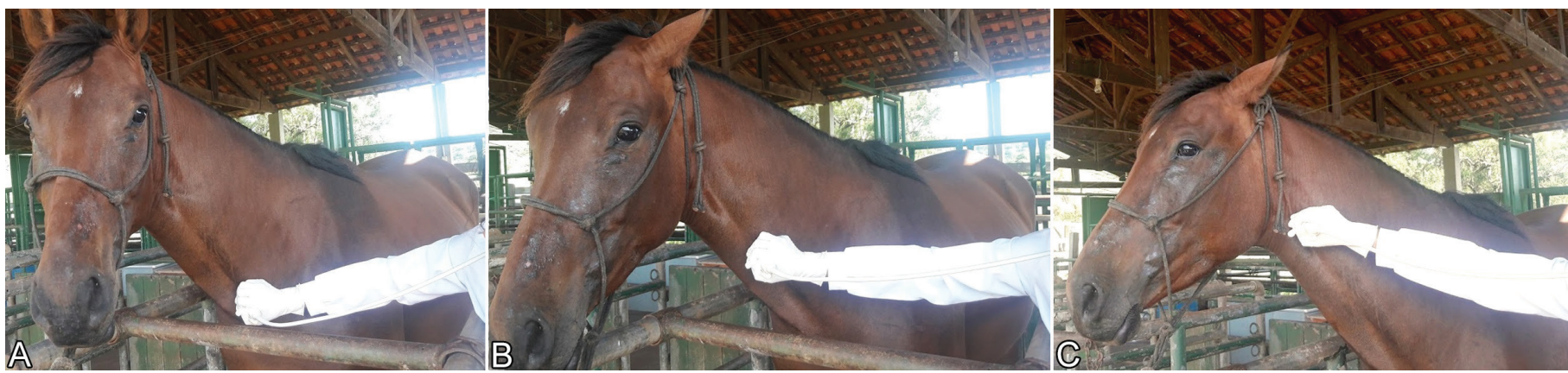

Fig.1. The images were obtained in the longitudinal and transversal plane of the animals, being (A) caudal, (B) medium and (C) cranial.
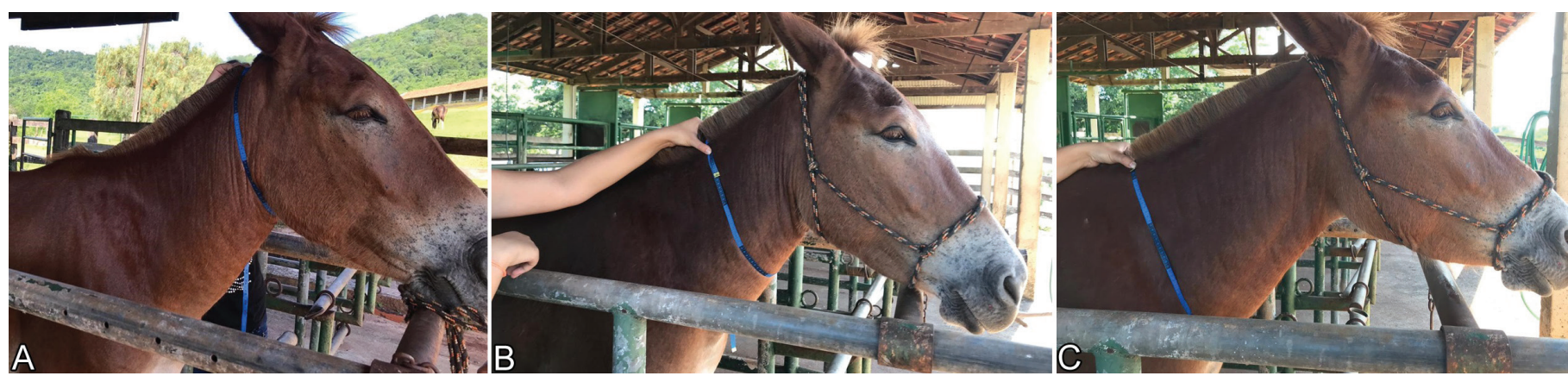

Fig.2. Measurements of the necks of the animals, being (A) cranial circumference, (B) medium and (C) base of the neck. 
Table 1. Mean and standard deviation of descriptive variables in equine females and mules

\begin{tabular}{|c|c|c|c|c|c|c|c|c|}
\hline \multirow[b]{2}{*}{ Variables } & \multicolumn{4}{|c|}{ Mules $(\mathrm{N}=11)$} & \multicolumn{4}{|c|}{ Equine females $(\mathrm{N}=11)$} \\
\hline & Mean & $\begin{array}{l}\text { Standard } \\
\text { deviation }\end{array}$ & Minimum & Maximum & Mean & $\begin{array}{l}\text { Standard } \\
\text { deviation }\end{array}$ & Minimum & Maximum \\
\hline Body mass (kg) & 368 & 72 & 175 & 462 & 413 & 42 & 348 & 486 \\
\hline Age (years) & 8 & 3 & 3 & 12 & 14 & 7 & 5 & 25 \\
\hline Base of the neck $(\mathrm{cm})$ & 104 & 5 & 96 & 113 & 104 & 5 & 96 & 110 \\
\hline Medium (cm) & 87 & 5 & 75 & 92 & 83 & 4 & 77 & 90 \\
\hline Cranial $(\mathrm{cm})$ & 71 & 7 & 52 & 77 & 71 & 6 & 63 & 83 \\
\hline Neck length $(\mathrm{cm})$ & 39 & 3 & 36 & 48 & 44 & 3 & 38 & 50 \\
\hline
\end{tabular}

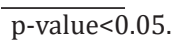

Table 2. Spearman's correlation test between the variables of interest: age, body mass, base of the neck, medium, cranial, neck length, longitudinal and transversal diameter and longitudinal and transversal wall of mules

\begin{tabular}{|c|c|c|c|c|c|c|c|}
\hline Variables & Statistic & Age & Body mass & Base of the neck & Medium & Cranial & Neck length \\
\hline \multirow[t]{2}{*}{ Age } & r & 1.00 & 0.32 & 0.53 & 0.46 & 0.61 & 0.31 \\
\hline & $\mathrm{p}$-value & & $0.0140 *$ & $<0.001^{*}$ & $0.0003^{*}$ & $<0.001^{*}$ & $0.0165^{*}$ \\
\hline \multirow[t]{2}{*}{ Body mass } & $\mathrm{r}$ & 0.32 & 1.00 & 0.60 & -0.04 & -0.04 & -0.02 \\
\hline & p-value & $0.0140^{*}$ & & $<0.001^{*}$ & 0.7608 & 0.7623 & 0.8505 \\
\hline \multirow[t]{2}{*}{ Base of the neck } & r & 0.53 & 0.60 & 1.00 & 0.60 & 0.65 & 0.69 \\
\hline & p-value & $<0.001^{*}$ & $<0.001^{*}$ & & $<0.001^{*}$ & $<0.001^{*}$ & $<0.001^{*}$ \\
\hline \multirow[t]{2}{*}{ Medium } & r & 0.46 & -0.04 & 0.60 & 1.00 & 0.88 & 0.85 \\
\hline & p-value & $0.0003^{*}$ & 0.7608 & $<0.001^{*}$ & & $<0.001^{*}$ & $<0.001^{*}$ \\
\hline \multirow[t]{2}{*}{ Cranial } & r & 0.61 & -0.04 & 0.65 & 0.88 & 1.00 & 0.83 \\
\hline & p-value & $<0.001^{*}$ & 0.7623 & $<0.001^{*}$ & $<0.001^{*}$ & & $<0.001^{*}$ \\
\hline \multirow[t]{2}{*}{ Neck length } & r & 0.31 & -0.02 & 0.69 & 0.85 & 0.83 & 1.00 \\
\hline & $\mathrm{p}$-value & 0.0165 & 0.8505 & $<0.001^{*}$ & $<0.001^{*}$ & $<0.001^{*}$ & \\
\hline Variables & Statistic & $\begin{array}{l}\text { Longitudinal } \\
\text { diameter }\end{array}$ & & $\begin{array}{l}\text { Transversal } \\
\text { diameter }\end{array}$ & $\begin{array}{l}\text { Longitudinal } \\
\text { wall }\end{array}$ & & $\begin{array}{l}\text { Transversal } \\
\text { wall }\end{array}$ \\
\hline \multirow[t]{2}{*}{ Age } & $\mathrm{r}$ & 0.70 & & 0.63 & 0.09 & & 0.08 \\
\hline & p-value & $<.0001^{*}$ & & $<.0001^{*}$ & 0.5265 & & 0.5824 \\
\hline \multirow[t]{2}{*}{ Body mass } & r & 0.29 & & 0.29 & -0.28 & & -0.06 \\
\hline & $\mathrm{p}$-value & $0.0407^{*}$ & & $0.0403^{*}$ & $0.0497^{*}$ & & 0.6710 \\
\hline \multirow[t]{2}{*}{ Base of the neck } & r & 0.64 & & 0.71 & -0.02 & & 0.05 \\
\hline & p-value & $<.0001^{*}$ & & $<.0001^{*}$ & 0.8925 & & 0.7176 \\
\hline \multirow[t]{2}{*}{ Medium } & r & 0.55 & & 0.58 & 0.28 & & -0.02 \\
\hline & p-value & $<0.001^{*}$ & & $<0.001^{*}$ & $0.0397^{*}$ & & 0.8589 \\
\hline \multirow[t]{2}{*}{ Cranial } & r & 0.58 & & 0.62 & 0.19 & & 0.03 \\
\hline & p-value & $<0.001^{*}$ & & $<0.001^{*}$ & 0.1607 & & 0.8322 \\
\hline \multirow[t]{2}{*}{ Neck length } & $\mathrm{r}$ & 0.49 & & 0.57 & 0.21 & & 0.04 \\
\hline & p-value & $0.0001^{*}$ & & $<0.001^{*}$ & 0.1187 & & 0.7719 \\
\hline
\end{tabular}

$\overline{* p \text {-value }<0.05 . ~}$

was also a negative correlation with the longitudinal wall $(\mathrm{p}=0.0497)$.

For the base of the neck variable there were positive correlations with age $(p<0,001)$, body mass $(p<0.001)$, medium $(p<0.001)$, cranial $(p<0.001)$, neck length $(p<0.001)$, longitudinal diameter $(\mathrm{p}<0.001)$, and transversal diameter $(\mathrm{p}<0.001)$.

Regarding the middle of the neck variable, there were positive correlations with age $(\mathrm{p}=0.0003)$, base of the neck $(p<0.001)$, cranial $(p<0.001)$ and neck length $(p<0.001)$, longitudinal diameter $(\mathrm{p}<0.001)$, transversal diameter $(\mathrm{p}<0.001)$ and longitudinal wall $(\mathrm{p}=0.0397)$.
The cranial variable had positive correlations with age $(p<0.001)$, base of the neck $(p<0.001)$, middle of the neck $(\mathrm{p}<0.001)$, neck length $(\mathrm{p}<0.001)$, longitudinal diameter $(\mathrm{p}<0.001)$ and transversal diameter $(\mathrm{p}<0.001)$.

Table 3 shows the correlation of the variables of interest: body mass, age, diameters and IMT of the vessels and neck measurements in the equine females.

In Table 3 it can be observed that the age of equine females showed a positive correlation with the longitudinal wall $(\mathrm{p}=0.0431)$ and negative correlations with body mass $(p=0.0040)$ and base of the neck $(p=0.0217)$. 
As for the body mass variable, there were positive correlations with the base of the neck $(p<0.001)$, middle of the neck ( $\mathrm{p}<0.001)$, cranial $(\mathrm{p}<0.001)$, longitudinal diameter $(\mathrm{p}=0.0022)$ and transversal diameter $(\mathrm{p}=0.0122)$, and negative correlation with age $(\mathrm{p}=0.0040)$.

For the base of the neck variable there were positive correlations with body mass $(\mathrm{p}<0.001)$, middle of the neck $(p<0.001)$, cranial $(p<0.001)$ and longitudinal diameter $(\mathrm{p}=0.0364)$, and negative correlation with age $(\mathrm{p}=0.0217)$.

For the middle of the neck variable there were positive correlations with body mass $(\mathrm{p}<0.001)$, base of the neck $(\mathrm{p}<0.001)$ and cranial $(\mathrm{p}<0.001)$.

The cranial variable showed positive correlations with body mass $(\mathrm{p}<0.001)$, base of the neck $(\mathrm{p}<0.001)$ and middle of the neck $(\mathrm{p}<0.001)$.

As for the neck length variable in the equine females, no statistically significant correlation was observed with the variables analyzed. Table 4 illustrates the correlation of the variables of interest: Doppler, age, body mass, longitudinal and transversal diameter, longitudinal and transversal wall of the blood vessels of mules.

Table 4 shows that the RI variable has positive correlations with PI ( $p<0.001), S V(p=0.0367)$ and body mass ( $p=0.0044)$, and negative correlations with the transversal diameter $(\mathrm{p}=0.0254)$ and $\mathrm{DV}(\mathrm{p}=0.0010)$.
For the PI variable there were positive correlations with RI $(\mathrm{p}<0.001)$ and body mass $(\mathrm{p}=0.0002)$, and negative correlations with DV $(\mathrm{p}=<0.001)$ and MV ( $\mathrm{p}=0.0045)$.

The SV variable had positive correlations with MV $(p<0.001)$, VFI $(p<0.001), D V(p<0.001)$ and RI $(p=0.0367)$, and negative correlations with age $(\mathrm{p}=0.0367)$, longitudinal diameter $(\mathrm{p}=0.0010)$ and transversal diameter $(\mathrm{p}=0.0011)$.

The DV variable had positive correlations with $M V(p<0.001)$, VFI $(p<0.001)$ and SV $(p<0.001)$, and negative correlations with RI $(p=0.0010)$, PI $(p<0.001)$, body mass $(p=0.0264)$ and age $(\mathrm{p}=0.0336)$.

As for the MV variable, positive correlations were found with VFI $(p<0.001), S V(p<0.001)$ and DV $(p<0.001)$, and negative correlations with age $(p<0.001)$, body mass $(p=0.0111)$, longitudinal diameter $(\mathrm{p}=0.0014)$, transversal diameter $(\mathrm{p}=0.0036)$ and PI $(\mathrm{p}=0.0045)$.

With respect to the VFI variable, there were positive correlations with MV $(p<0.001), S V(p<0.001)$ and DV $(\mathrm{p}<0.001)$, and negative correlations with age $(\mathrm{p}=0.0006)$, longitudinal diameter $(\mathrm{p}=0.0055)$ and transversal diameter $(p=0.0055)$. Table 5 illustrates the correlation of the variables: Doppler, age, body mass, longitudinal and transversal diameter, longitudinal and transversal blood vessel wall of equine females; and shows that the RI variable had positive correlations with PI $(p<0.001), S V(p<0.001)$, VFI $(p=0.0355)$, longitudinal $(\mathrm{p}<0,001)$ and transversal diameter $(\mathrm{p}=0.0002)$,

Table 3. Spearman's correlation test between the variables of interest: age, body mass, base of the neck, medium, cranial, longitudinal and transversal diameter and longitudinal and transversal wall of equine females

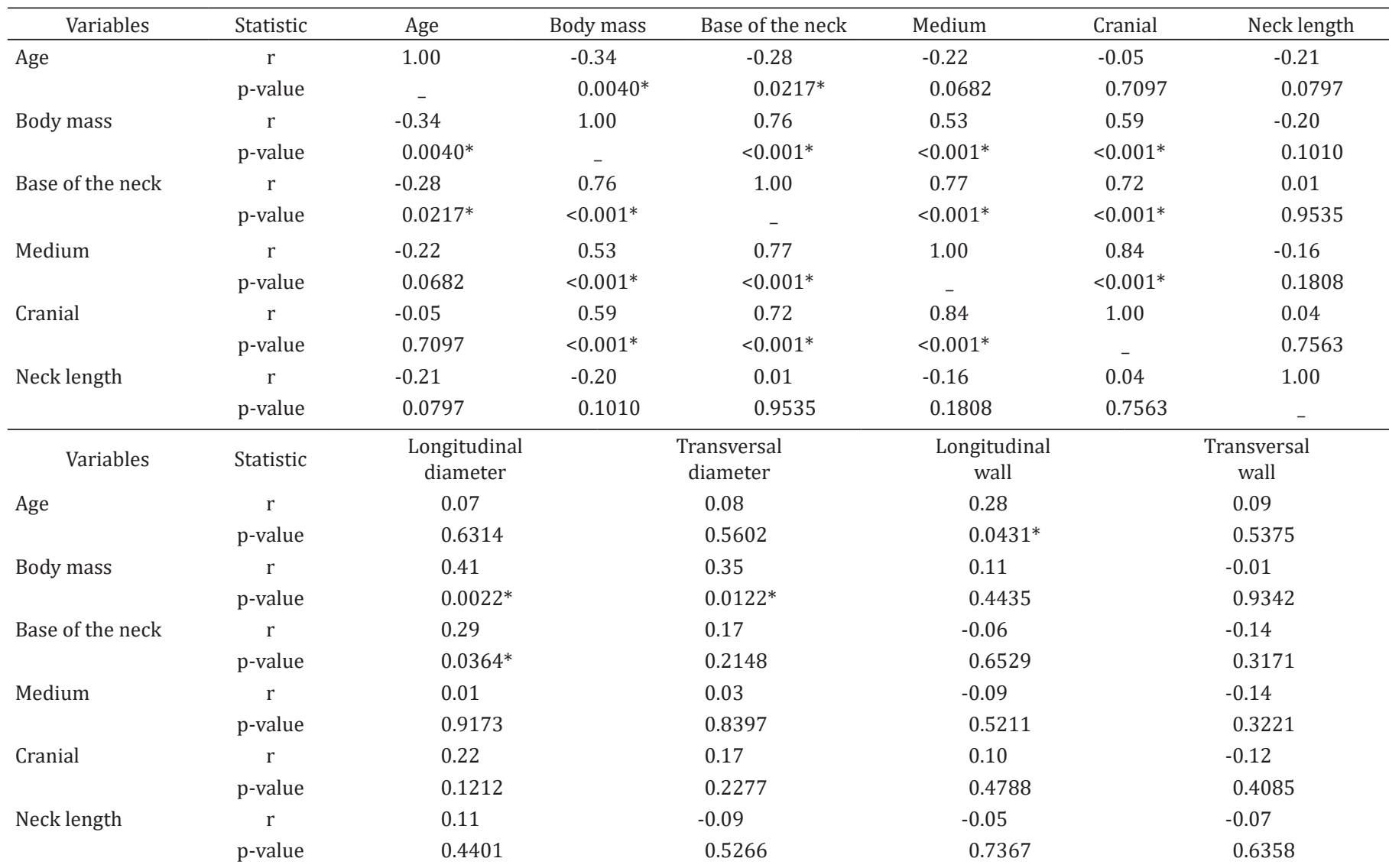

$\overline{* p \text {-value }<0.05}$. 
Table 4. Spearman's correlation test between the variables of interest: RI, PI, SV, DV, MV, VFI, age, body mass, longitudinal and transversal diameter and longitudinal and transversal wall of mules

\begin{tabular}{|c|c|c|c|c|c|c|}
\hline Variables & RI & PI & SV & DV & MV & VFI \\
\hline \multirow[t]{2}{*}{ RI } & 1.00 & 0.93 & 0.26 & -0.40 & -0.15 & -0.05 \\
\hline & & $<0.001^{*}$ & $0.0367^{*}$ & $0.0010^{*}$ & 0.2352 & 0.7107 \\
\hline \multirow[t]{2}{*}{ PI } & 0.93 & 1.00 & 0.11 & -0.48 & -0.35 & -0.23 \\
\hline & $<0.001^{*}$ & & 0.3703 & $<0.001^{*}$ & $0.0045^{*}$ & 0.0579 \\
\hline \multirow[t]{2}{*}{ SV } & 0.26 & 0.11 & 1.00 & 0.61 & 0.85 & 0.84 \\
\hline & $0.0367^{*}$ & 0.3703 & & $<0.001^{*}$ & $<0.001^{*}$ & $<0.001^{*}$ \\
\hline \multirow[t]{2}{*}{ DV } & -0.40 & -0.48 & 0.61 & 1.00 & 0.81 & 0.72 \\
\hline & $0.0010^{*}$ & $<0.001^{*}$ & $<0.001^{*}$ & & $<0.001^{*}$ & $<0.001^{*}$ \\
\hline \multirow[t]{2}{*}{ MV } & -0.15 & -0.35 & 0.85 & 0.81 & 1.00 & 0.94 \\
\hline & 0.2352 & $0.0045^{*}$ & $<0.001^{*}$ & $<0.001^{*}$ & & $<0.001^{*}$ \\
\hline \multirow[t]{2}{*}{ VFI } & -0.05 & -0.23 & 0.84 & 0.72 & 0.94 & 1.00 \\
\hline & 0.7107 & 0.0579 & $<0.001^{*}$ & $<0.001^{*}$ & $<0.001 *$ & \\
\hline Variables & Age & Body mass & $\begin{array}{l}\text { Longitudinal } \\
\text { diameter }\end{array}$ & $\begin{array}{c}\text { Transversal } \\
\text { diameter }\end{array}$ & $\begin{array}{l}\text { Longitudinal } \\
\text { wall }\end{array}$ & $\begin{array}{c}\text { Transversal } \\
\text { wall }\end{array}$ \\
\hline \multirow[t]{2}{*}{ RI } & -0.03 & 0.36 & -0.23 & -0.30 & -0.11 & -0.22 \\
\hline & 0.8309 & $0.0044^{*}$ & 0.0945 & $0.0254^{*}$ & 0.4280 & 0.1077 \\
\hline \multirow[t]{2}{*}{ PI } & 0.14 & 0.47 & -0.07 & -0.17 & -0.17 & -0.18 \\
\hline & 0.2784 & $0.0002^{*}$ & 0.6001 & 0.2211 & 0.2031 & 0.1760 \\
\hline \multirow[t]{2}{*}{ SV } & -0.42 & -0.12 & -0.43 & -0.42 & -0.06 & -0.18 \\
\hline & $0.0008^{*}$ & 0.3653 & $0.0010^{*}$ & $0.0011^{*}$ & 0.6734 & 0.1836 \\
\hline \multirow[t]{2}{*}{ DV } & -0.27 & -0.29 & -0.22 & -0.19 & 0.04 & 0.05 \\
\hline & $0.0336^{*}$ & $* 0.0264$ & 0.0992 & 0.1504 & 0.7742 & 0.6948 \\
\hline \multirow[t]{2}{*}{ MV } & -0.52 & -0.33 & -0.42 & -0.38 & 0.02 & -0.03 \\
\hline & $<0.001^{*}$ & $* 0.0111$ & $0.0014^{*}$ & $0.0036^{*}$ & 0.8829 & 0.8053 \\
\hline \multirow[t]{2}{*}{ VFI } & -0.43 & -0.18 & -0.37 & -0.36 & 0.01 & -0.10 \\
\hline & $0.0006^{*}$ & 0.1580 & $0.0055^{*}$ & $0.0063^{*}$ & 0.9437 & 0.4603 \\
\hline
\end{tabular}

$\overline{\mathrm{RI}}=$ resistivity index, $\mathrm{PI}=$ pulsatility index, SV = systolic velocity, DV = diastolic velocity, $\mathrm{MV}=$ maximum velocity, $\mathrm{VFI}=$ vascular flow index; * $\mathrm{p}$-value $<0.05$.

longitudinal blood vessel wall $(\mathrm{p}=0.0328)$ and age $(\mathrm{p}=0.0045)$, and negative correlation with DV ( $p=0.0029)$.

In the case of the PI variable, there were positive correlations with RI $(p<0.001), S V(p<0.001)$, age $(p=0.0020)$, longitudinal $(p<0.001)$ and transversal diameter $(p=0.0003)$, and negative correlation with DV (0.0043).

For the SV variable, there were positive correlations with $\operatorname{MV}(p<0.001), V F I(p<0.001), R I(p<0.001), \operatorname{PI}(p<0.001)$ and DV $(\mathrm{p}=0.0002)$.

The DV variable showed positive correlations with MV $(\mathrm{p}<0.001), S V(p=0.0002)$ and VFI $(\mathrm{p}<0.001)$, and negative correlations with RI ( $\mathrm{p}=0.0029)$, PI $(0.0043)$, body mass (0.0392), longitudinal diameter $(\mathrm{p}=0.0009)$ and transversal diameter $(\mathrm{p}=0.0123)$.

The MV variable had positive correlations with VFI $(\mathrm{p}<0.001)$, SV $(\mathrm{p}<0.001)$ and DV $(\mathrm{p}<0.001)$.

The VFI variable had positive correlations with MV $(\mathrm{p}<0.001), S V(p<0.001), D V(p<0.001)$ and RI $(p=0.0355)$.

\section{DISCUSSION}

Several studies about the carotid arteries have been done in a great number of animals, such as camels (Darweesh et al. 1989), buffaloes (Prakash \& Rao 1976), bovines (Khamas \& Mahdi 1984, Braun \& Fohn 2005) and dogs (Hess et al. 2003), among others. However, studies involving B-mode and spectral
Doppler ultrasonography have been few, especially involving these animals and equines. Some studies with B-mode and spectral Doppler ultrasonography of the common carotid arteries of equines have been reported (Cipone et al 1997, Schmucker et al. 2000, Aguiar 2015). However, reports involving studies on mules or any large species except equines have not been found in the literature consulted.

Mules are hybrid equidae originating from the crossing between mares and donkeys and, although equines and donkeys share a common ancestry, they have significant morphological differences. Thus, it is to be expected that mules will present some anatomo-physiological differences from equines. However, there are few studies on equines which do not involve domestic horses, and so there is a dearth of information on mules (Burnhan 2002, Alsafy et al. 2008, Smith 2009). It is important that studies about these animals be undertaken, and especially about their common carotid arteries, which are responsible for carrying the oxygen-rich blood flow directly to the brain. Any change in the functioning of these vessels can cause severe neurological issues in the individual (Rosa et al. 2003, Chequer et al. 2006, Kobayashi \& Karino 2016).

The intima - media layer thickness (IMT) and the diameter of common carotid arteries provide structural and anatomic information, just as the cardiac cycle variation provides 
Table 5. Spearman's correlation test between the variables of interest: RI, PI, SV, DV, MV, VFI, age, body mass, longitudinal and transversal diameter and longitudinal and transversal wall of equine females

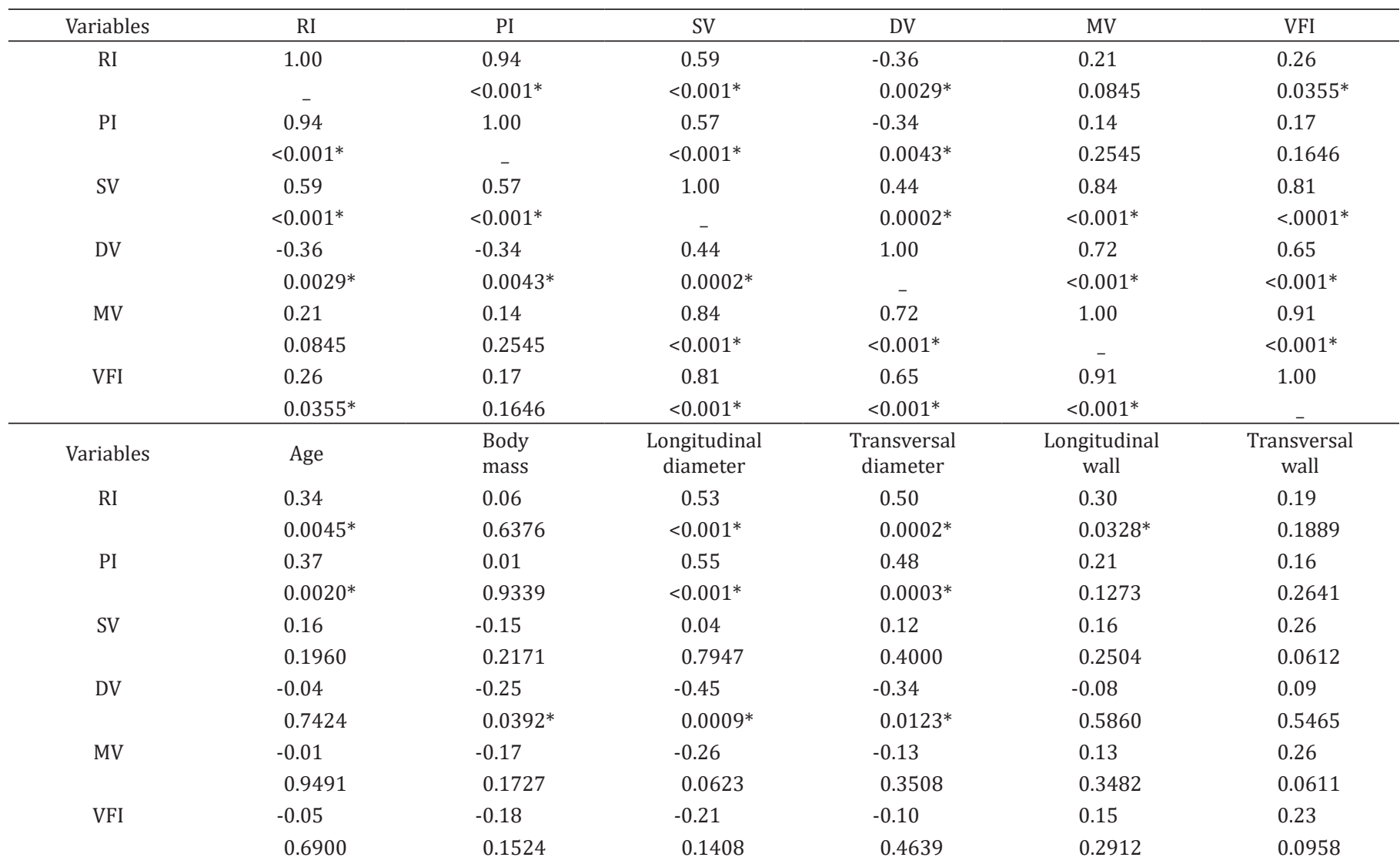

$\overline{\mathrm{RI}}=$ resistivity index, PI = pulsatility index, $\mathrm{SV}=$ systolic velocity, $\mathrm{DV}=$ diastolic velocity, $\mathrm{MV}=$ maximum velocity, $\mathrm{VFI}=\mathrm{vascular}$ flow index; ${ }^{*} \mathrm{p}-\mathrm{value}<0.05$.

functional information (Caviezel et al. 2013, Aguiar 2015). IMT and the diameter of common carotid arteries are essential variables to diagnose stenosis and the presence of atherosclerotic plaques, including in the equine and canine species (Rosa et al. 2003, Hess et al. 2003, Coll et al. 2013, Aguiar et al. 2014, Kiyota 2014).

Krejza et al. (2006) have carried out work involving B-mode and spectral Doppler ultrasonography for the evaluation of common carotid arteries in humans (306 women and 194 men). Measurements of the circumferences and lengths of necks were used to obtain the correlation with the diameter and IMT of the common carotid arteries. It was found that women had lower values for the diameter, IMT, body mass, circumference and neck length. The present research evaluated the common carotid arteries in three regions: caudal, middle and cranial. This was done because in equines and mules the common carotid arteries vary along their length (Furuhata 1964).

Mules averaged higher values for neck circumference in the middle region, while at the base of the neck and in terms of cranial circumference both mules and equine females showed equivalent values. Mules probably have higher values for neck circumference due to being small and robust animals (Chirgwin et al. 2000). As for body mass, age and neck length, it was found that equine females had higher values.
In the evaluation according to age, mules had positive correlations with body mass, longitudinal and transversal diameter and neck circumference (base of the neck, middle region and cranial). In equine females, age had a positive correlation with the vessels' longitudinal wall; similar to what was found by Aguiar (2015) in the Quarter horse breed, and negative correlations with body mass and the base of the neck. It was found that the age of equine females did not have significant correlations with the diameters of the common carotid arteries, unlike the results obtained by Aguiar (2015) with equines and Krejza et al. (2006), Torres et al. (2007), Freitas et al. (2008) and Coll et al. (2013) in humans.

Regarding the body mass variable, mules showed positive correlations with age, longitudinal and transversal diameter of the neck and base of the neck. On the other hand, equine females were found to have positive correlations with the longitudinal and transversal diameter and with neck circumference, including neck length. It was possible to ascertain that the body mass of all animals influenced in the longitudinal and transversal diameter of the common carotid arteries, similarly to what had been found by Higa (2009) and Denarie et al. (2000) and Zanini (2012) in humans and by Cipone et al. (1997) and Aguiar (2015) in equines.

Body mass also influenced the neck circumference of equine females (base of the neck region and head), as did age in mules. 
This correlation of body mass with neck circumference had already been mentioned by Krejza et al. (2006) in humans, and males showed a wider variability.

Regarding spectral Doppler parameters, it was observed that the RI variable of mules showed a positive correlation with PI, SV and body mass, and negative correlations with DV and transversal diameter. In equine females there were positive correlations with PI, SV, VFI, age and longitudinal and transversal diameter, and negative correlation with DV, that is, there was a positive correlation between the variable RI with body mass in mules, while in equine females that correlation is with age, as reported by Aguiar (2015) in equines and by Barbosa et al. (2006) in humans. A positive correlation was also found between RI and the longitudinal and transversal diameter of the neck in equine females, while in mules this correlation was negative.

Very high values of RI reduce DV, and, depending on the issue that is causing the increase in resistance of the vessel, DV absence may be observed. SV is the most reliable measuring variable to determine the degree of obstruction of the vessel studied, since the reduction in blood flow occurs after stenosis, but can also be observed when there is a reduction of DV (Bragato 2013). Thus, hemodynamic indices such as RI, PI and SV help in the comparison between SV and DV, collaborating in the diagnosis of stenosis or thrombosis of peripheral vessels with increased resistance (Hedrick et al. 1995).

In humans it is observed that, depending on the degree of stenosis of the common or internal carotid artery, an alteration of the distal blood flow may occur. Light degrees of stenosis result in reduced blood flow (VFI), increase of SV near the point of stenosis and increase of RI and PI. These alterations point to an increase in resistance and a reduction of the vascular compliance of the carotid artery, that is, a reduction of the arterial blood flow through the artery in question. Severe degrees may result in significant reduction of the blood flow speed (SV, MV, DV), or the flow may become absent or even negative (reverse) (Johnston et al. 1981, Kaproth-Joslin et al. 2014).

These findings are normally more prominent the closer the measurement point is to the change, although they may also be observed in cases of vascular spasm, carotid dissection and in inflammatory processes. Another common occurrence is increased arterial blood flow through the contralateral carotid to compensate for the reduced blood flow in the brain and thus avoid ischemic brain lesions. On the other hand, the alteration of the blood flow in the two common carotids is more indicative of a diffuse arterial inflammatory process or of intracranial changes such as increased intracranial pressure or diffuse intracerebral vascular spasm (Johnston et al. 1981, Kaproth-Joslin et al. 2014).

The PI has been suggested for the standardization of blood flow, as it is more sensitive to differentiate abnormal waves (Moreira et al. 2008), and both PI and RI are measured independently of the angle of insonation (Pozor \& McDonnell 2004, Bailey et al. 2012).

Regarding the PI variable of mules, positive correlations were observed with RI and body mass, and negative correlations with DV and MV. On the other hand, in equine females the PI variable showed positive correlations with RI, SV, age and longitudinal and transversal diameter, and negative correlation with DV, that is, a positive correlation was observed between the PI and body mass in mules. As for female equines, that correlation was observed with age, as found by Aguiar (2015) in equines and Barbosa et al. (2006) in humans.

The RI normally has a positive correlation with the PI and negative correlation with DV (Carvalho 2009, Kiyota 2014), and this correlation has been observed in both equine and mule females, as this procedure allows the evaluation of vessel resistance and blood flow speed. High values of RI indicate lower arterial elasticity, that is, greater vascular resistance in the irrigated region. There is, however, a correlation between the increase of carotid RI and atherosclerosis risk factors (Carvalho 2009, Kiyota 2014).

For the SV variable, positive correlations were observed with MV, VFI, DV and RI, and negative correlations with age, longitudinal and transversal diameter in mules. In the case of equine females, positive correlations were found with MV, VFI, DV, PI and RI, and no negative correlation, contrasting with what has been reported by Cipone et al. (1997), who observed a negative correlation with vessel diameters in equines. In the present study this was observed statistically only in mules, unlike what Hansen et al. (1995) reported in humans, in whom there is a positive correlation between these variables.

According to Appleton \& Hatle (1992), in humans SV is inversely proportional to age, and in this work this has been statistically identified only in mules, and was not found to be relevant in equine females.

As for the DV variable in mules, it showed positive correlations with MV, VFI and SV, and negative correlations with RI, PI and body mass. In equine females positive correlations were found with MV, VFI and SV, and negative correlations with RI, PI, body mass and transversal diameter. It was observed that both in mules and equine females body mass is inversely proportional to the DV variable, just as pointed out by Appleton \& Hatle (1992) in humans.

In mules, the MV variable had positive correlations with the VFI, SV and DV variables, and negative correlations with PI, age, body mass, longitudinal and transversal diameter. Regarding equine females, positive correlations were observed with VFI, SV and DV and no negative correlation, unlike what was reported by Cipone et al. (1997), who found a negative correlation with vessel diameters in equines. However, this was statistically verified only in mules.

Schmidt-Trucksass et al. (1999) observed an indirectly proportional correlation between MV and age in humans, a response identical to that found in mules. However, the association between these variables has been studied and correlated with age (Barbosa et al. 2006).

As for the VFI variable, positive correlations were noticed with MV, SV and DV, and negative correlations with age, longitudinal and transversal diameter in mules. In equine females only positive correlations with MV, SV, DV and RI were observed. In spite of the results noted about VFI, there are still no reports of any correlation involving this variable in equines in the consulted literature.

\section{CONCLUSIONS}

The correlations analyzed showed variations between equine and mule females.

Neck circumference is greater in mules than in equine females, but length is greater in equines. 
In mules age influences neck circumference, while in equine females it influences body mass.

All neck regions are positively correlated in all animals.

Vessel diameters are related with all regions in mules, but in equine females only with the base of the neck.

The resistivity index (RI) and pulsatility index (PI) are positively correlated with body mass in mules and with age in equine females.

Systolic velocity (SV) influences age negatively only in mules, and diastolic velocity (DV) influences body mass in all animals.

Maximum speed (MV) and vascular flow index (VFI) are negatively connected with age and with diameters only in mules.

Conflict of interest statement. - The authors report no conflict of interest.

\section{REFERENCES}

Aguiar A. 2015. Avaliação ultrassonográfica da artéria carótida comum em equinos da raça quarto de milha. Master's Thesis, Faculdade de Medicina Veterinária de Botucatu, Universidade Estadual Paulista, Botucatu, SP. 77p.

Aguiar A., Dantas A., Viana G.F. \& Machado V.M.V. 2014. Ateroma em artéria carótida comum de equino detectado através de exame ultrassonográfico, relato de caso. IV Simpósio Internacional de Diagnóstico por Imagem Veterinário, Belo Horizonte, MG. 3p.

Alsafy M.A.M., El-Kammar M.H. \& El-Gendy S.A.A. 2008. Topographical anatomy, computed tomography and surgical approach of the guttural pouches of the donkey. J. Equine Vet. Sci. 28(4):215-222. <http://dx.doi. org/10.1016/j.jevs.2008.02.005>

Appleton C.P. \& Hatle L.K. 1992. The natural history of left ventricular filling abnormalities: assessment by two-dimensional and Doppler echocardiography. Echocardiography 9(4):437-457. <http://dx.doi. org/10.1111/j.1540-8175.1992.tb00486.x>

Bailey C.S., Sper R.B., Schewmaker J.L., Buchanan C.N., Beachler T.M., Pozor M.A. \& Whitacre M.D. 2012. Uterine artery blood flow remains unchanged in pregnant mares in response to short-term administration of pentoxifylline. Theriogenology 77(2):430-436.<http://dx.doi.org/10.1016/j. theriogenology.2011.08.018 > <Mid:21958635>

Barbosa M.F., Abdala N., Carrete-Junior H., Nogueira R.G., Nalli D.R., Fonseca J.R.F. \& Szejnfeld J. 2006. Doppler transcraniano convencional em voluntários assintomáticos. Arq. Neuropsiquiatr. 64(3):829-838. <http://dx.doi. org/10.1590/S0004-282X2006000500023><PMid:17057893>

Bonamigo T.P. \& Lucas M.L. 2007. Análise crítica das indicações e resultados do tratamento cirúrgico da doença carotídea. J. Vasc. Bras. 6(4):366-377. <http://dx.doi.org/10.1590/S1677-54492007000400011>

Borges M.C.B., Tinoco A.C., Graça Filho U.C., Leandro E.S., Lopes A.R.G., Coutinho D.P., Lopes M.A.F. \& Cerqueira R.B. 2005. Timpanismo e empiema de bolsa gutural conseqüente a garrotilho. Revta Ciênc. Méd. Biol. 4(2):125-130. <http://dx.doi.org/10.9771/cmbio.v4i2.4184>

Bragato N. 2013. Ultrassonografia Doppler vascular: aspectos importantes para a aplicação da técnica. Master's Thesis, Escola de Veterinária e Zootecnia, Universidade Federal de Goiás, Goiás, GO. 62p.

Braun U. \& Föhn J. 2005. Duplex ultrasonography of the common carotid artery and external jugular vein of cows. Am. J. Vet. Res. 66(6):962-965. <http://dx.doi.org/10.2460/ajvr.2005.66.962> <PMid:16008216>

Burnhan S.L. 2002. Anatomical differences of the donkey and mule. AAEP Proceedings 48(1):102-109.

Carvalho C.F. 2009. Ultrassonografia Doppler em Pequenos Animais. Roca, São Paulo, p.1-110.
Caviezel S., Dratva J., Schaffner E., Teynor A., Baumstark M.W., Schindler C., de Groot E., Burdet L., Rothe T., Pons M., Gaspoz J.M., Rochat T., Künzli N., Probst-Hensch N. \& Schmidt-Trucksäss A. 2013. Variability and reproducibility of carotid structural and functional parameters assessed with transcutaneous ultrasound - results from the sapaldia cohort study. Atherosclerosis 231(2):448-455. < http://dx.doi.org/10.1016/j. atherosclerosis.2013.10.010><PMid:24267265>

Chequer G., Nascimento B.R., Navarro T.P., Falqueto E.B., Alencar M.C., de Miranda M.C., Mandil A., Saad J.A., Fonseca C. \& Ribeiro A.L. 2006 Espessamento médio-intimal da carótida e função endotelial na doença arterial coronariana. Arq. Bras. Cardiol. 87(2):84-90. <http://dx.doi. org/10.1590/S0066-782X2006001500004><PMid:16951824>

Chirgwin J.C., Roover P. \& Dijkman J.T. 2000. El burro como animal de trabajo. Estudio FAO Producción y Sanidad Animal, Organización de las Naciones Unidas para la Agricultura y la Alimentación, p.1-3.

Cipone M., Pietra M., Gandini G., Boari A., Guglielmini C. \& Venturoli M. 1997. Pulsed wave-doppler ultrasonographic evaluation of the common carotid artery in the resting horse: physiologic data. Vet. Radiol. Ultrasound 38(3):200-206. <http://dx.doi.org/10.1111/j.1740-8261.1997.tb00841. $\mathrm{x}><$ PMid:9238791>

Coll B., Betriu A., Feinstein S.B., Valdivielso J.M., Zamorano J.L. \& Fernández E 2013. The role of carotid ultrasound in assessing carotid atherosclerosis in individuals at low-to-intermediate cardiovascular risk. Revta Esp. Cardiol. 66(12):929-934. <http://dx.doi.org/10.1016/j.recesp.2013.05.030> $<$ PMid:24774105>

Darweesh E.G., Khamas W.A. \& Al-Shaikhly A.K. 1989. Termination of the common carotid artery in one humped camel (Camelus dromedaries). Iraqi J. Vet. Med. 15(1):1-10

Denarié N., Gariepy J., Chironi G., Massonneau M., Laskri F., Salomon J., Levenson J. \& Simon A. 2000. Distribution of ultrasonographically assessed dimensions of common carotid arteries in healthy adults of both sexes. Atherosclerosis 148(2):297-302. <http://dx.doi.org/10.1016/S00219150(99)00276-2><PMid:10657565>

Freitas P.D., Piccinato C.E., Martins W.D.P. \& Mauad-Filho F. 2008. Aterosclerose carotídea avaliada pelo eco-Doppler: associação com fatores de risco e doenças arteriais sistêmicas. J. Vasc. Bras. 7(4):298-307. <http://dx.doi. org/10.1590/S1677-54492009005000001>

Furuhata K. 1964. Morphological studies of the trifurcate portions of the common carotid arteries and the so-called intercarotid bone in the horse. Jpn. J. Vet. Res. 12(3):47-60.

Getty R. 1981. Anatomia dos Animais Domésticos. 5a ed. Interamericana, Rio de Janeiro, p.528-548.

Hansen F., Mangell P., Sonesson B. \& Länne T. 1995. Diameter and compliance in the human common carotid artery: variations with age and sex. Ultrasound Med. Biol. 21(1):1-9. <http://dx.doi.org/10.1016/0301-5629(94)000905> <PMid:7754568>

Hayah N. 2011. A study of the anatomical variations of the carotid arterial tree in equidae. PhD Dissertation, University of Glasgow, Scotland. 186p.

Hedrick W.R., Hykes D.L. \& Starchman D.E. 1995. Ultrasound Physics and Instrumentation: practice examinations 3rd ed. Mosby-Year Book, St Louis. 56p.

Hess R.S., Kass P.H. \& Van Winkle T.J. 2003. Association between diabetes mellitus, hypothyroidism or hyperadrenocorticiosm, and atherosclerosis in dogs. J. Vet Intern. Med. 17(4):489-494. <http://dx.doi.org/10.1111/j.1939-1676.2003. tb02469.x><PMid:12892299>

Higa M. 2009. Métodos para quantificação da artéria carótida em imagens de ultrassom modo-B e Doppler. Master's Thesis, Escola Politécnica, Universidade de São Paulo, SP. 79p. <http://dx.doi.org/10.11606/D.3.2009. tde-11082010-163813>

Johnston K.W., Morais D., Kassam M. \& Brown P.M. 1981. Cerebrovascular assessment using a doppler carotid scanner and real-time frequency 
analysis. J. Clin. Ultrasound 9(8):443-449. <http://dx.doi.org/10.1002/ jcu.1870090808><PMid:6795239>

Kandiah N., Goh O., Mak E., Marmin M. \& Ng A. 2014. Carotid stenosis: a risk factor for cerebral white-matter disease. J. Stroke Cerebrovasc. Dis. 23(1):136139. <http://dx.doi.org/10.1016/j.jstrokecerebrovasdis.2012.11.007> $<$ PMid:23265783>

Kaproth-Joslin K.A., Bhatt S., Scoutt L.M. \& Rubens D.J. 2014. The essentials of extracranial carotid ultrasonographic imaging. Radiol. Clin. 52(6):13251342. <http://dx.doi.org/10.1016/j.rcl.2014.07.010><PMid:25444109>

Khamas W.A. \& Mahdi A.H. 1984. Light microscopic study of the internal carotid artery, carotid body of the bull. Iraqi J. Vet. Sci. 8:51-55.

Khamas W.A.H., Al-Hallak M.A. \& Ghoshal N.G. 2002. Terminal branches of the common carotid artery in mule with emphasis on the carotid body and carotid sinus. Vet. Arc. 72(1):1-10.

Kiyota T.A. 2014. Idade pulmonar está relacionada a alterações estruturais carotídeas em indivíduos hipertensos. Master's Thesis, Faculdade de Ciências Médicas, Universidade Estadual de Campinas. 61p.

Kobayashi N. \& Karino T. 2016. Flow behavior and distribution of embolusmodel particles at the terminal bifurcation of the human internal cartotid artery. World Neurosurg. 90(1):469-477. <http://dx.doi.org/10.1016/j. wneu.2016.03.012><PMid:26987631>

Krejza J., Arkuszewski M., Kasner S.E., Weigele J., Ustymowicz A., Hurst R.W., Cucchiara B.L. \& Messe S.R. 2006. Carotid artery diameter in men and women and the relation to body and neck size. Stroke 37(4):1103-1105. <http:// dx.doi.org/10.1161/01.STR.0000206440.48756.f7><PMid:16497983>

Krupinski J., Turu M.M., Martinez-Gonzalez J., Carvajal A., Juan-Babot J.0., Iborra E., Slevin M., Rubio F. \& Badimon L. 2006. Endogenous expression of c-reactive protein is increased in active (ulcerated noncomplicated) human carotid artery plaques. Stroke 37(1):1200-1204. <http://dx.doi. org/10.1161/01.STR.0000217386.37107.be> <PMid:16601222>

Mendes R. \& Themudo Barata J.L. 2008. Envelhecimento e pressão arterial. Acta Med. Port. 21(2):193-198. <PMid:18625098>

Moreira H.R., Miranda S.A., Brito A.B., Pereira W.L. \& Domingues S.F. 2008. Complexo hiperplasia endometrial cística em uma cadela tratada com aspecto de medroxiprogesterona como método contraceptivo. Revta Port. Ciênc. Vet. 103(1):233-238.

Ozgel O., Kurtul I. \& Dursun N. 2004. On the gross anatomy of the cranial cervical ganglion of the donkey (Equus asinus) in turkey. Vet. Res. Commun. 28(4):261-266. <http://dx.doi.org/10.1023/B:VERC.0000026659.91446. c8><PMid:15222730>
Paiva-de-Souza A.V., Xavier-Silva B., Antunes M.S., Hernandez J.M.F., Scherer P.O. \& Abidu-Figueiredo M. 2010. Frequency of caroticobasilar artery in crossbred horses: Anatomical study for experimental research. Pesq. Vet. Bras. 30(8):685-688. <http://dx.doi.org/10.1590/S0100-736X2010000800013>

Pessoa A.F.A., Pessoa C.R.M., Miranda Neto E.G. \& Riet-Correa F. 2014. Doenças de asininos e muares no semiárido brasileiro. Pesq. Vet. Bras. 34(12):12101214. <http://dx.doi.org/10.1590/S0100-736X2014001200011>

Pozor M.A. \& Mcdonnell S.M. 2004. Color Doppler ultrasound evaluation of testicular blood flow in stallions. Theriogenology 61(5):799-810. <http:// dx.doi.org/10.1016/S0093-691X(03)00227-9><PMid:14757466>

Prakash P. \& Rao G.S. 1976. A morphological study of the carotid body and the fiber content of the carotid nerve in the buffalo. Acta Anat. 95(2):249-259. <http://dx.doi.org/10.1159/000144617><PMid:961356>

Ribeiro K.C. \& Shintaku R.C.O. 2004. A influência dos lipídios da dieta sobre aterosclerose. Conscientiae Saúde 3(3):73-83.

Rosa E.M., Kramer C. \& Castro I. 2003. Association between coronary artery atherosclerosis and the intima-media thickness of the common carotid artery measured on ultrasonography. Arq. Bras. Cardiol. 80(6):589-592.<http:// dx.doi.org/10.1590/S0066-782X2003000600002><PMid:12856069>

Schmidt-Trucksäss A., Grathwohl D., Schmid A., Boragk R., Upmeier C., Keul J. \& Huonker M. 1999. Structural, functional, and hemodynamic changes of the common carotid artery with age in male subjects. Arterioscler. Thromb. Vasc. Biol. 19(4):1091-1097. <http://dx.doi.org/10.1161/01. ATV.19.4.1091><PMid:10195940>

Schmucker N., Schatzmann U., Budde K., Gundel M., Jäggin C.E. \& Meier H. 2000. Duplex-ultrasonographic evaluation of the common carotid artery in the resting, sedated and anesthetized horse. Vet. Radiol. Ultrasound 41(2):168-171. <http://dx.doi.org/10.1111/j.1740-8261.2000.tb01472. $\mathrm{x}><$ PMid:10779078>

Smith D.C. 2009. The book of mules: selecting, breeding and caring for equine hybrids. The Lyons Press, Connecticut. 136p.

Torres F.S., Moreira C.M., Vianna F.F. \& Gus M. 2007. Medida da espessura das camadas íntima e média das artérias carótidas para avaliação do risco cardiovascular. Revta Bras. Hipertens. 14(3):167-197.

Zanini J.L.S.S. 2012. Características das artérias carótidas de adolescentes saudáveis ao ultrassom com Doppler. Master's Thesis, Faculdade de Medicina, Universidade Federal de Minas Gerais, Belo Horizonte, MG. 87p. 